UDC $378.311 .3(045)$,

DOI: $10.18372 / 1990-5548.52 .11869$

\author{
${ }^{1}$ V. M. Kazak, \\ ${ }^{2}$ I. V. Prokhorenko, \\ ${ }^{3}$ N. A. Tymoshenko
}

\title{
IMPACT OF TRAINING PROCESS OF AVIATION SPECIALISTS ON FLIGHT SAFETY PARAMETERS
}

\author{
${ }^{1}$ Educational \& Recearch Center of Advanced Technologies, National Aviation University, Kyiv Ukraine \\ ${ }^{2}$ Department of automation and energy management, Research Institute of integrated telecommunication \\ technologies, National Aviation University, Kyiv Ukraine \\ E-mails; ${ }^{1}$ profkazak@ukr.net, ${ }^{2}$ Prokhorenkoirina83@gmail.com, ${ }^{3}$ t_nataly@ukr.net
}

\begin{abstract}
The possibility of increasing the efficiency of training process management of aviation specialists by optimizing the time structure. is considered here. It is established that the process of perception and remembering of information is influenced by: the time allocated, the structure and sequence of educational material, the formation of information links between the blocks of educational information, the frequency of the use of concepts and the speed of information transfer. On the basis of the analysis of the training process of aviation specialists, its structuring was carried out, determined management and control influences on the training process of aviation specialists, as the essential controlling variable in the work, the distribution of operating time is taken as the basis.
\end{abstract}

Index Terms - Flight safety; training the specialists; optimization; subjective entropy; subjective advantages.

\section{INTRODUCTION}

Flight safety (BP) is a major issue for civil aviation (CA) in any country and is seen as the property of the aviation transport system to carry air transport without endangering people's lives and health. An analysis of the FS state under the auspices of the International Civil Aviation Organization (ICAO) indicates that the overwhelming majority of six aviation events occur for reasons related to the "personal" or "human" factor (HF). The analysis of the flight safety proves the necessity of reforming the existing AS system [1], [2]. Therefore, a lot of attention is paid to this issue.

\section{ANALYSIS OF RECENT RESEARCH AND PUBLICATIONS}

Under the conditions of overcoming crisis phenomena in the economy, the question of the quality of flight technicians training increases the relevance of the issue. The main reason for this is the inconsistency of the training quality of educational institutions' graduates to the requirements of the industry and transport enterprises. This problem is devoted to the works of national scientists, such as: E. Vinograd, E. Zharikov, O. Razumovsky, G. Shirshin, A. Uemov, V. Yatskevich. Thus, the question of the correspondence of professional training level of flight crew is the most relevant under the conditions of evolutionary changes in the theory of the FS provision [3]-[4].

The purpose of this article is to increase the efficiency of the practical training management of the flight crew by optimizing the time structure.

\section{PROBlem StATEMENT}

Since the process of preparing a flight technical profile requires the attraction of significantly more resources than in other fields of knowledge, the high level of logistics and optimal use of all available resources, such as material, financial, personnel, time, etc., is needed to achieve the required training quality. Solving such a complex problem requires the implementation of mathematical methods to support the adoption of managerial decisions on the formation of optimal strategies and timely correction of current learning methods in accordance with changes in internal and external conditions, dynamics of knowledge, changes in goals and priorities of training. The main tool for this should be the modern methods of modeling and optimization, which will allow to predict the development of events, the consequences of certain management decisions, and most importantly, will allow you to find the best solutions to improve professional skills.

The main task of this work is to investigate the influence of the distribution of active current time (operating time) of subjects of study (students) on the quality of education parameters, while the quality of learning is determined on the basis of the testing results. The authors tried to give a theoretical scheme of problem analysis based on the most general preconditions. The obtained model allows us to carry out a parametric analysis [3].

The qualitative structure implies that in this case the learning process has three components:

- information component of training process;

- modifications of the learner intelligence;

- improving the ethical basis. 
Thus, the effectiveness of subjects' educational activities should be based on constant monitoring of the level of these three components. The management of the development and interdependence of such components allows us to form a coherent and consistent model of a highly qualified specialist. Let's consider each of the components in detail.

The information component implies solving the following tasks:

- the choice of educational information content, which corresponds to the given direction or specialty, which the subject learns;

- structuring the content and the time during which portions of educational information are grasped;

A characteristic feature in solving mentioned problems is the management of the students' resources and the choice of teaching technology.

The management of students' intellectual capacity development can be achieved through the improvement of the basic properties of intelligence, namely:

- development of logical thinking;

- increase the speed of processing training information;

- increase of the possible amount of information that the subject can master;

- solving the problem of choice, if there is a multi-alternative situation.

The defining component that needs to be solved is the modification of students' ethical foundations. The concept of this component is based on ensuring the successful solution of previous two components. The main environment in which you can realize the influence of intelligence - information component. The development of methods for assessing the modification of intellectual and ethical foundations represents the second component.

In this context, the capacity of a future specialist to master new information, and to replace the obsolete information with a new one will be high when a future specialist is characterized by a high degree of adaptability to new dynamically changing conditions in their field. The implementation at a desired level of the first and the second tasks is not possible without solving the third one. In this sense, the management and evaluation of the training process's effectiveness should be oriented not on the end result of graduation, but on the active work of a specialist all the time, just as the design of the aircraft and its equipment is currently carried out, taking into account the reliability of its entire life cycle. Two types of aviation personnel training are considered:

- passive training;

- problem training.
Passive training - is to transfer the planned scope and content of information.

This method does not provide the trainee with the opportunity to make a right decision for the situation prevailing in flight or when preparing for it.

Problem training - involves creating problem situations in the process of managing the process of preparing specialists, when the student is placed in the conditions necessary to make decisions: to make choices (strategies) $\sigma_{i} \in S_{a}$, where $S_{a}$ there is a set of permissible alternative solutions.

The ability to make decisions on a plurality $S_{a}$ is conditioned, firstly, by the ability to perceive, recognize, identify an alternative, evaluate the implications associated with it - resource costs $R^{\text {req }}\left(\sigma_{i}\right)$ are expected resources, and secondly: the ability to make choices $S_{a}$ in uncertainty.

This ability depends on the accumulated experience, decision-making skills and is based on the characteristic of the will of those who study. Creating the necessary basis for what we have described is provided by the information component of learning technology. Creating the necessary foundation is provided in the process of problem training.

Consider that $T$ is the total resource of the operating time of training, hence $\bar{t}_{\text {inf }}=\frac{t_{\text {inf }}}{T}-$ the relative operating time of the information component, $\bar{t}_{\mathrm{pr}}=\frac{t_{\mathrm{pr}}}{T}-$ the relative time of problem training:

$$
\bar{t}_{\text {inf }}+\bar{t}_{\mathrm{pr}}=1 .
$$

It's obvious that the more $\bar{t}_{\text {inf }}$, the more reliable and deep awareness of problem-wise situations is created in the classroom, but also the smaller the number of different situations it can cover.

On the contrary, the more $\bar{t}_{\mathrm{pr}}$, the greater the plurality $S_{a}$ and the faster the right decision can be made. Thus, there are obvious "scales" when planning a training strategy for aviators. Therefore, it is proposed to divide the training time into two parts: $t_{\text {inf }}^{*}-$ information time, $t_{\mathrm{pr}}^{*}-$ problem time, where the asterisk affects the optimal choice. As an example, let's consider a separate case of a fixed number of alternatives: $N=2, \sigma_{1}, \sigma_{2} \in \sigma_{n}$ so we will focus on using as a criterion for optimizing time, making a decision. We associate it with the so-called entropy thresholds. Let's define the subjective entropy $S_{a}$ as follows:

$$
H_{\pi}=-\sum_{i=1}^{N} \pi\left(\sigma_{i}\right) \ln \pi\left(\sigma_{i}\right),
$$


where $\pi\left(\sigma_{i}\right)$ is the indicator of the preference of the alternative $\sigma_{i}$.

Values $\pi\left(\sigma_{i}\right)$ are not probabilities but satisfy certain conditions of normalization, within the framework of the theory of cognitive measure:

$$
\sum_{i=1}^{N} \pi\left(\sigma_{i}\right)=1
$$

Under the conditions of uncertainty, any nonadditive measure may be used, for example, the measure of Sugeno or the so-called non-additive Hmeasure, where the condition of normalization is taken as:

$$
\sum_{i=1}^{N} \pi_{i}\left(\sigma_{i}\right)+\lambda H_{\pi}=1
$$

or

$$
\sum_{i=1}^{N} \pi\left(\sigma_{i}\right) \cdot\left(1-\lambda \ln \pi\left(\sigma_{i}\right)\right)=1
$$

To get a model of function $\pi\left(\sigma_{i}\right.$ in work, the benefits are used. The most appropriate for the realization of this task is the information-entropy method, which coincides in the form with the principle of James, but at the same time, has significant differences, and therefore can be considered an independent principle [5]. As the criterion of optimality the value is taken:

$$
\begin{aligned}
\Phi_{\pi}=\alpha(\lambda) \sum_{i=1}^{N} & \pi\left(\sigma_{i}\right) \ln \pi\left(\sigma_{i}\right) \\
& \pm \sum_{i=1}^{N} \pi\left(\sigma_{i}\right) F\left(\sigma_{i}\right)+\gamma \sum_{i=1}^{N} \pi\left(\sigma_{i}\right),
\end{aligned}
$$

where $\beta$ is the endogenous structural parameter considered as a characteristic of the emotional stress and the internal peculiarity of the subject in the formation of the functions of benefits; $F\left(\sigma_{i}\right)$ is the "cognitive" function.

After calculating the derivative of $\Phi_{\pi}$ on $\bar{\pi}\left(\sigma_{i}\right)$, we find:

$$
\alpha(\lambda, \gamma)\left(\ln \pi\left(\sigma_{i}\right)+1\right) \pm \beta F_{i}\left(\sigma_{i}\right)+\gamma=0,
$$

from here:

$$
\pi\left(\sigma_{i}\right)=\frac{\exp \left( \pm \frac{\beta}{\alpha(\lambda, \gamma)} \cdot F_{i}\left(\sigma_{i}\right)\right)}{\sum_{q=1}^{N} \exp \left( \pm \frac{\beta}{\alpha(\lambda, \gamma)} \cdot F_{q}\left(\sigma_{a}\right)\right)} .
$$

An assumption about the existence of subjective entropy thresholds is made:
$-H_{\pi}^{*}$ is the solution threshold;

- $H_{\pi}^{* *}$ is a upper level of psychological uncertainty;

- $H_{\pi^{*}}$ is the threshold of evolutionary "nonreturn". lows:

The necessary condition for the decision is as fol-

$$
H_{\pi}\left\langle H_{\pi}^{*}\right.
$$

If $H_{\pi} \geq H_{\pi}^{*}$ is the decision on $S_{a}$ can't be made. If $H_{\pi}\left\langle H_{\pi}^{*}\right.$ is the decision can't be changed. If $\left.H_{\pi}\right\rangle H_{\pi}^{* *}$ is the psyche of the person making the decision is in a state of deep stress and no rational activity is possible.

The distribution (8) coincides in the form with the Baltsman-Gibbs distribution in physical kinetics, and the coefficient $\beta^{\prime}= \pm \frac{\beta}{\alpha(\lambda, \gamma)}-$ has the role of the reverse "mental" temperature $\beta^{\prime}=\frac{1}{T}$.

Figure 1 shows the characteristic dependence on time when the problem situation arises.

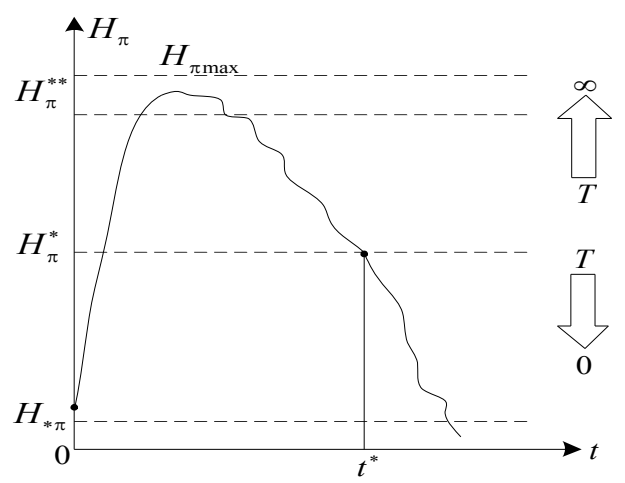

Fig. 1. Dependence of subjective entropy on time

We can conclude from the analysis of data in Fig. 1 that when a special problem situation arises, subjective entropy $H_{\pi}$ rapidly increases and the subject enters the area of "stress" $H_{\pi} \in\left[H_{\pi}^{*}, H_{\pi}^{* *}\right]$, and then under constant conditions the subject gradually recovers.

Entropy falls in the moment $t=t^{*}$ caused by the necessary condition for a timely decision [3]. The dynamics of entropy depends on $\beta$ and on the cognitive function $F\left(\sigma_{i}\right)$. It is assumed that $\beta$ is a function of $\bar{t}_{\mathrm{pr}}$ and this dependence can be shown by the logistic curve.

$$
\bar{\beta}\left(T_{p}\right)=\bar{\beta}_{\min }+\left(\bar{\beta}_{\max }-\bar{\beta}_{\min }\right) e^{-h \tau_{r}^{2}} .
$$


Let's present the cognitive function $F_{i}\left(\sigma_{i}\right)$ as:

$$
F_{i}\left(\sigma_{i}\right)=\bar{F}_{i}\left(\sigma_{i}\right) m
$$

where $\bar{F}_{i}\left(\sigma_{i}\right)$ depends largely on other circumstances, and $m$ mainly depends on $T_{\text {inf }}=\frac{T-t_{\text {inf }}}{t_{\text {inf }}}$. Then

$$
m_{i}\left(\tau_{\mathrm{inf}}\right)=m_{\min }+\left(m_{i \max }-m_{i \min }\right) e^{-g_{i} \tau_{\text {inf }}^{2}} .
$$

It is necessary to estimate additionally the magnitude of subjective and objective risks, that is, the risk of a third kind. If there are two objects $A_{1}$ and $A_{2}$ in the space of the parameter $a$ of the object (system), and then $a \in A_{1}$ is a successful result of the existing flight situation, if $a \in A_{2}$ is an unsuccessful result, it is highly undesirable:

$$
\begin{aligned}
R_{o b j}= & c_{11} p\left(\sigma_{i}\right) \cdot P\left(a \in A_{1} \mid \sigma_{1}\right) \\
+ & c_{12} p\left(\sigma_{2}\right) \cdot P\left(a \in A_{1} \mid \sigma_{2}\right) \\
+ & c_{21} p\left(\sigma_{1}\right) \cdot P\left(a \in A_{2} \mid \sigma_{1}\right) \\
& \quad+c_{22} p\left(\sigma_{2}\right) \cdot P\left(a \in A_{2} \mid \sigma_{2}\right) .
\end{aligned}
$$

The hybrid model has also been studied in which it is assumed that a priori probabilities can be written down by the magnitudes of the corresponding advantages. Therefore, we introduce the subjective Bayesian risk:

$$
\begin{aligned}
R_{s u b j}=c_{11} \pi\left(\sigma_{i}\right) & \hat{P}\left(a \in A_{1} \mid \sigma_{1}\right) \\
+c_{12} \pi\left(\sigma_{2}\right) & \cdot \hat{P}\left(a \in A_{1} \mid \sigma_{2}\right) \\
+ & c_{21} \pi\left(\sigma_{1}\right) \cdot \hat{P}\left(a \in A_{2} \mid \sigma_{1}\right) \\
& +c_{22} \pi\left(\sigma_{2}\right) \cdot \hat{P}\left(a \in A_{2} \mid \sigma_{2}\right) .
\end{aligned}
$$

If, as a cognitive function, subjective Bayesian risk is used, then the functional will take the form:

$$
\begin{aligned}
\Phi_{\pi} & =-\alpha(\lambda, \gamma) \sum_{i=1}^{N} \pi\left(\sigma_{i}\right) \ln \pi\left(\sigma_{i}\right) \\
& \pm R_{\text {subj }} \pi\left(\sigma_{1}\right),\left(\pi\left(\sigma_{2}\right), \ldots \pi\left(\sigma_{N}\right)\right)+\gamma \sum_{i=1}^{N} \pi\left(\sigma_{i}\right) .
\end{aligned}
$$

But the canonical distribution has an exponential character:

$$
\begin{aligned}
& \pi\left(\sigma_{i}\right)=\exp \\
& {\left[\frac{\frac{+\beta}{\alpha(\lambda, \gamma)}\left(c_{21} \cdot \hat{P}\left(a \in A_{2} \mid \sigma_{1}+c_{21} \cdot \hat{P}\left(a \in A_{2} \mid \sigma_{1}\right)\right)\right)}{\sum_{i=1}^{2} \sum_{j=1}^{2} \exp \left[\frac{+\beta}{\alpha(\lambda, \gamma)} \cdot\left(c_{21} \cdot \hat{P}\left(a \in A_{j} \mid \sigma_{i}\right)\right]\right.}\right]}
\end{aligned}
$$

where $\hat{P}\left(a \in A_{j} \mid \sigma_{i}\right)$ is the subjective probability in Groot's terminology. The threshold height $H^{*}$ depends on time. The higher the threshold, the faster the decision will be made, and the higher the probability of a decision that is not the best in terms of security.

The amount of information time ( $\left.t_{\text {inf }}\right)$ influences the quality and depth of flight situation identification and alternatives, including its increase, promotes a more distinct differentiation of alternatives, an increase in the absolute difference between cognitive functions:

$$
\delta F_{i j}=\left(F\left(\sigma_{i}\right)-F\left(\sigma_{j}\right) .\right.
$$

There is a problem of choosing the optimal program in the division of the training time in two parts: 1) $t_{\text {inf }}$ is the information time; 2) $t_{\mathrm{pr}}^{*}$ is a problem time.

\section{CONCLUSION}

The following approach to quantitative assessing the impact of time structure optimization of aviation specialists training process on the conditions of the assigned level of FS allows the formation of the necessary volitional qualities of future specialists. The introduction of this approach to the training process of aviation specialists will enable to enhance the level of their readiness to the actions in extreme situations both in the field and on the land.

\section{REFERENCES}

[1] V. Zhulev, V. Ivanov, Safety of Flight Operations. Moscow, Transport, 1986, $224 \mathrm{p}$.

[2] V. Ovcharov, Human Factor in Aviation Incidents. Moscow, MAK, 2005, $80 \mathrm{p}$.

[3] V. M. Kazak, Systemic Methods of Restoration of Aircraft Survivability in Special Flight Situations. Kyiv, NAU, 2010, 284 p.

[4] O. Savinov, Modeling and Quality Management of Aviation Specialists Training. Kyiv, NAU, 2010, 170 p.

[5] V. O. Kasyanov, Subjective Analysis. Kyiv, NAU, 2007, $512 \mathrm{p}$. 
Kazak Vasily. Doctor of Engineering Science. Professor. Director.

Educational \& Recearch Center of Advanced Technologies, National Aviation University, Kyiv Ukraine.

Education: Kiev Higher Engineering Aviation Military School, (1972).

Research interests: methods of recovering survivability of airplanes in special flight situations, control and diagnostics dynamic systems, optimal control complex systems

Publications: 312 .

E-mail: profkazak@ukr.net

Prohorenko Irina. Candidate of Science (Engineering).

Department of automation and energy management, Research Institute of integrated telecommunication technologies, National Aviation University, Kyiv Ukraine.

Education: National Aviation University, Kyiv Ukraine, (2005).

Research interests: optimizing allocation of teaching time in the preparation of aviation engineering personnel.

Publications: 34.

E-mail: Prokhorenkoirina@gmail.com

Tymoshenko Nataliia. Candidate of Science (Engineering).

Department of automation and energy management, Research Institute of integrated telecommunication technologies, National Aviation University, Kyiv Ukraine.

Education: National Aviation University, Kyiv Ukraine, (2005).

Research interests: automation of aircraft control process.

Publications: 32 .

E-mail: t_nataly@ukr.net

В. М. Казак, І. В. Прохоренко, Н. А. Тимошенко. Вплив процесу підготовки авіаційних фахівців на показники безпеки польотів

Розглянуто можливість підвищення ефективності керування процесом підготовки авіаційних кадрів,шляхом оптимізації часової структури процесу їхньої підготовки. Встановлено, що на процес сприйняття і запам'ятовування інформації впливають: кількість відведеного часу, структура та послідовність навчального матеріалу, утворення інформаційних зв'язків між блоками навчальної інформації, частота використання понять і швидкість передачі інформації. На підставі аналізу процесу підготовки авіаційних фахівців проведено його структуризацію, визначені керовані та керуючі впливи на процес підготовки авіаційних фахівців, як істотну керуючу змінну в роботі за основу взято розподіл операційного часу.

Ключові слова: безпека польотів; підготовка фахівців; оптимізація; суб'єктивна ентропія; суб'єктивні переваги.

Казак Василь Миколайович. Доктор технічних наук. Професор. Директор.

Навчально-науковий центр новітніх технологій, Національний авіаційний університет, Київ, Україна.

Освіта: Київське вище інженерне авіаційне військове училище, (1972).

Наукові інтереси: методи відновлення живучості ЛА у особливих ситуаціях у польоті, керування та діагностика динамічних систем, оптимальне керування складними системами

Публікації: 312.

E-mail: profkazak@ukr.net

Прохоренко Ірина Володимирівна. Кандидат технічних наук.

Кафедра автоматизації та енергоменеджменту, Науково-дослідний інститут інтегрованих телекомунікаційних технологій, Національний авіаційний університет, Київ, Україна.

Освіта: Національний авіаційний університет, Київ, Україна (2005)

Напрямок наукової діяльності: оптимізація розподілу навчального часу в процесі підготовки інженерних авіаційних кадрів.

Публікації: 34

E-mail: Prokhorenkoirina@gmail.com

Тимошенко Наталія Анатоліївна. Кандидат технічних наук.

Кафедра автоматизації та енергоменеджменту, Науково-дослідний інститут інтегрованих телекомунікаційних технологій, Національний авіаційний університет, Київ, Україна.

Освіта: Національний авіаційний університет, Київ, Україна (2005)

Напрямок наукової діяльності: автоматизація процесів керування літальними апаратами.

Публікації: 32

E-mail: t_nataly@ukr.net 
В. М. Казак, И. В. Прохоренко, Н. А. Тимошенко. Влияние процесса подготовки авиационных специалистов на показатели безопасности полетов

Рассмотрена возможность повышения эффективности управления процессом подготовки авиационных кадров, путем оптимизации временной структуры процесса их подготовки. Установлено, что на процесс восприятия и запоминания информации влияют: количество отведенного времени, структура и последовательность учебного материала, образования информационных связей между блоками учебной информации, частота использования понятий и скорость передачи информации. На основании анализа процесса подготовки авиационных специалистов проведено его структуризацию, определенные управляемые и управляющие воздействия на процесс подготовки авиационных специалистов, как существенную управляющую переменную в работе за основу взято распределение операционного времени.

Ключевые слова: безопасность полетов; подготовка специалистов; оптимизация; субъективная энтропия; субъективные предпочтения

Казак Василий Николаевич. Доктор технических наук. Профессор. Директор.

Учебно-научный центр новейших технологий, Национальный авиационный университет, Киев, Украина.

Образование: Киевское высшее инженерное авиационное военное училище, (1972).

Научные интересы: методы восстановления живучести ЛА в особых ситуациях в полете, управление и диагностика динамических систем, оптимальное управление сложными системами

Публикации: 312.

E-mail: profkazak@ukr.net

Прохоренко Ирина Владимировна. Кандидат технических наук.

Кафедра автоматизации и энергоменеджмента, Научно-исследовательский институт интегрированных телекоммуникационных технологий, Национальный авиационный университет, Киев, Украина.

Образование: Национальный авиационный университет, Киев, Украина (2005)

Направление научной деятельности: оптимизация распределения учебного времени в процессе подготовки инженерных авиационных кадров.

Публикации: 34

E-mail: Prokhorenkoirina@gmail.com

Тимошенко Наталия Анатольевна. Кандидат технических наук.

Кафедра автоматизации и энергоменеджмента, Научно-исследовательский институт интегрированных телекоммуникационных технологий, Национальный авиационный университет, Киев, Украина.

Образование: Национальный авиационный университет, Киев, Украина (2005)

Направление научной деятельности: автоматизация процессов управления летательными аппаратами.

Публикации: 32

E-mail: t_nataly@ukr.net 